\title{
Militancy of nurses in the institutionality field: printed media versions
}

\author{
Militância de enfermeiras no campo da institucionalidade: versões da mídia impressa \\ Militancia de enfermeras en el campo de la institucionalidad: versiones de los medios impresos
}

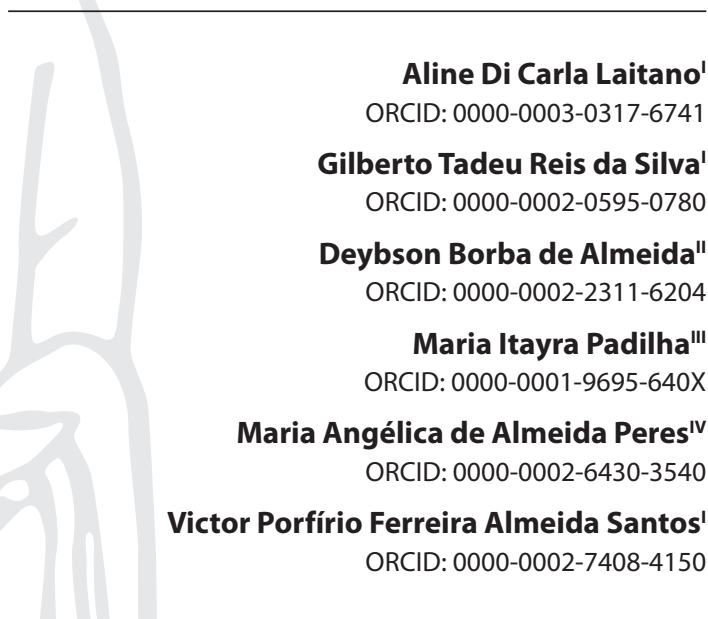

'Universidade Federal da Bahia. Salvador, Bahia, Brazil. "Universidade Estadual de Feira de Santana. Feira de Santana, Bahia, Brazil. "'Universidade Federal da Santa Catarina. Florianópolis, Santa Catarina, Brazil.

"Universidade Federal do Rio de Janeiro. Rio de Janeiro, Rio de Janeiro, Brazil.

How to cite this article: Laitano ADC, Silva GTR, Almeida DB, Padilha MI, Peres MAA, Santos VPFA. Militancy of nurses in the institutionality field: printed media versions.

Rev Bras Enferm. 2020;73(4):e20180835. doi: http://dx.doi.org/10.1590/0034-7167-2018-0835

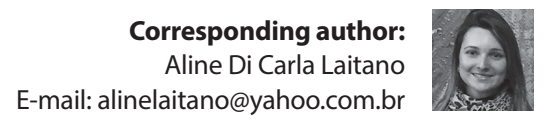

EDITOR IN CHIEF: Dulce Aparecida Barbosa ASSOCIATE EDITOR: Italo Rodolfo Silva

\begin{abstract}
Objectives: to analyze nurses' professional militancy in the institutionality field, presented by the printed media from Bahia State in the 1970s and 1980s. Methods: a historical and qualitative research under Social History's perspective, whose data source was the newspaper A Tarde. The temporal cut-off encompasses milestones such as professional body restructuring and creation. Results: the Associação Brasileira de Enfermagem democratization movement was reported in a superficial way, highlighting the struggle for power spaces. With respect to Conselhos Federal e Regional de Enfermagem da Bahia, the newspaper notified creation and function of bodies, however, there was no visibility to the newspaper's performance. Concerning the union, there was political fragility of nurses against the creation and union participation in the fight for labor rights. Final Considerations: organization of political action occurred from isolated groups mobilization of professionals who were already traveling in political spaces, not the large mass of professionals.

Descriptors: Journalism; Politics; Societies, Nursing; Political Activism; Nursing.
\end{abstract}

\section{RESUMO}

Objetivos: analisar a militância profissional de enfermeiras no campo da institucionalidade com base nas notícias publicadas namídia impressa baiana nas décadas de 1970 e 1980. Métodos: pesquisa histórica, com abordagem qualitativa na perspectiva da História Social, cuja fonte de dados foi o jornal $A$ Tarde. $O$ recorte temporal abarca o período de reestruturação e criação das entidades profissionais. Resultados: o movimento de democratização da Associação Breasileira de Enfermagem foi noticiado de forma superficial, evidenciando a luta pelos espaços de poder. Com relação ao Conselhos Federal e Regional de Enfermagem da Bahia, o jornal comunicou a criação e função dos órgãos, porém não conferiu visibilidade às suas atuações. Sobre o sindicato, foi destacada a fragilidade política das enfermeiras diante da sua criação e participação sindical na luta por direitos trabalhistas. Considerações Finais: a organização dos espaços de atuação política decorreu da mobilização de grupos isolados de profissionais que já transitavam nos espaços políticos, e não da grande massa de profissionais.

Descritores: Jornalismo; Política; Sociedades de Enfermagem; Ativismo Político; Enfermagem.

\section{RESUMEN}

Objetivos: analizar la militancia profesional de enfermeras en el campo de la institucionalidad, presentada por los medios impresa baiana, en las décadas de 1970 y 1980. Métodos: investigación histórica con abordaje cualitativo en la perspectiva de la Historia Social, cuya fuente de datos fue el diario $A$ Tarde. El recorte temporal abarca marcos como la reestructuración y creación de las entidades profesionales. Resultados: el movimiento de democratización de la Associação Brasileira de Enfermagem fue noticiado de forma superficial, dejando en evidencia la lucha por los espacios de poder. Con respecto al Conselhos Federal e Regional de Enfermagem da Bahia, el periódico comunicó la creación y función de los órganos, sin embargo, no dio visibilidad a su actuación. Sobre el sindicato, se evidenció la fragilidad política de las enfermeras frente a la creación y participación sindical en la lucha por derechos laborales. Consideraciones Finales: la organización de los espacios de actuación política se debió a la movilización de grupos aislados de profesionales que ya transitaban en los espacios de políticos y no de la gran masa de profesionales.

Descriptores: Periodismo; Política; Sociedades de Enfermería; Activismo Político; Enfermería. 


\section{INTRODUCTION}

A Militancy is a form of critical and engaged political participation exercised through actions aimed at political awareness seeking to develop new values that enable people to organize and fight for a just and dignified society ${ }^{(1)}$.

In the nursing field, militancy must change, since a vision committed to the individual and the society from ethical, political and social points of view avoid the worrying and unconditional acceptance of pre-established rules without any questioning ${ }^{(2)}$. However, nurses ${ }^{1}$ are not assigned a history of political organization that brings together a significant number of female workers, which shows a silent majority in the health field. This group lacks reflections that promote effective professional engagement ${ }^{(3)}$.

The reduced involvement of nurses with political issues pervades training aspects and the work world. The model adopted by nursing schools for many years was based on the military standard, with a strong religious and moral connotation, which distanced future professionals from any militant activity ${ }^{(4)}$. Moreover, precarious working conditions often experienced can also hamper this political involvement, as there may be little time and incentive for them, given the long working hours ${ }^{(5)}$.

Professional entities offer a change perspective, since they are a space to aggregate workers, being able to favor critical-reflexive formation and political, social and professional context understanding in which they are in ${ }^{(6)}$. Participation in these institutions boosts discussions about profession and group-belonging feeling, enhancing actions directed at the collective.

Nevertheless, based on the assumption that participation in collective organizations enables engagement and political action, this study focused on militancy of nurses in these entities' institutionality. The study aimed to investigate how such militancy was disseminated by the printed media throughout a period characterized by emancipatory movements effervescence in society, especially in the dictatorship's last decades. It also aimed at redefining public health policies in the face of transformations that resulted in health reform in the 1980s; and changes in the nursing scope, which sought to build a new professional identity. This historical context of redemocratization and greater political openness encouraged the creation of nursing representative entities and women greater participation in politics and media ${ }^{(7)}$.

Furthermore, institutionality is the set of elements related to constitution, role, forms of functioning and structuring, and action strategies of professional nursing organizations comprised by the Brazilian Nursing Association (ABEn - Associação Brasileira de Enfermagem), Federal and Regional Nursing Councils (COFEN and COREN-BA - Conselhos Federal e Regional de Enfermagem) and Nurses of Bahia State Union (SEEB - Sindicato dos Enfermeiros do Estado da Bahia).

Overall, nurses do not have the tradition of expressing their work importance, nor do they provide enlightening information about the profession, which contributes to invisibility maintenance

1 Female nurses reference in this study derives from the understanding that the profession's genesis de-terminants cover aspects related to gender, religious, and military influences. They evidence the social and sexual division of labor in the nursing field. The issues imbricated with the figure of the woman in the course of profession history give elements that help in the understanding of its development. and lack of knowledge about their practice ${ }^{(8)}$. Therefore, rethinking profession status involves reflecting on the conception that society has of this category and the image that professionals hold.

During the 1970s and 1980s, ABEn experienced an intense process of restructuring, and created COREN, COFEN, and SEEB.

This study was carried out because of this period historical relevance and institutionality organization importance in the profession. Understanding struggle and militancy undertaken by nurses can reveal new perspectives of engaged action. Moreover, there is a gap in knowledge, since no studies were found that aimed at analyzing militancy through printed media dissemination.

\section{OBJETIVES}

To analyze nurses' professional militancy in the institutionality field, presented by the printed media from Bahia State in the 1970s and 1980s.

\section{METHODS}

\section{Ethical aspects}

According to the Research Ethics Committee with Human Beings (RECHB) of Resolution 466/12 of the Brazilian National Health Board (Conselho Nacional de Saúde) norms and guidelines, a project research submission to RECHB was waived, since this is a study that uses only public documents and free access.

\section{Study design}

This is a historical-documentary qualitative research under Social History's perspective.

\section{Study setting}

The study was based on Bahia State, a federative unit with the largest number of nurses in Northeastern Brazil and fourth in the country ${ }^{(9)}$. This may reinforce study expressiveness, in view of the concentration of professionals in Bahia. Moreover, Bahia is also historically recognized by the engaged political action of local nurses ${ }^{(10-13)}$, which contributed to profession development at local and national level.

\section{Methodological procedures}

Reports published in the newspaper $A$ Tarde and the main printed communication means published in Bahia State between the 1970s and the 1980s were chosen as data sources ${ }^{(14)}$.

In addition to historical facts rescue, journalism has been chosen because it understands that media is an important instrument in public opinion formation and, therefore, capable of promoting changes in behavior and concept. By their power of persuasion, representations conveyed in press tend to be perceived and assimilated as truths ${ }^{(15)}$. The written press choice as a research document is based on Social History's proposal, which has as a priority field human or human relations, so that social relations and ideologies are among the most obvious objects ${ }^{(16)}$.

The data were collected in the newspaper's digital gathering, available for access from computers of the Public Library of the 
Bahia State from September to October 2017. As newspaper gathering is digital, it was possible to search 7,300 newspaper editions published from $01 / 01 / 1970$ to $12 / 31 / 1989$ by using the search terms "Female nurse" and "Male nurse", which resulted in the identification of 1,666 reports. There were no searches with the term "Nursing" given finding in experimental gathering that reports addressing higher education professionals could be obtained using the first two search terms.

Of the total number of reports identified, 53 dealt with militant activity of nurses in favor of the profession. Twenty-eight nurses dealt with militancy in professional organizations' institutions. The other publications dealt with professional militancy in the training and work fields (16 reports and 24 reports) that will be discussed in future studies.

The data were analyzed by following content analysis' proposal in the thematic modality ${ }^{(17)}$. Data coding gave rise to the eight analysis units, which were organized and grouped by themes, resulting in three categories.

\section{RESULTS}

Results will be presented separately, according to ABEn, COFEN, COREN-BA, and SEEB. Charts 1, 2 and 3 present a sample of findings that exemplify the categories, as well as their themes.

Chart 1 - Militancy of nurses in the institutional framework of Brazilian Nursing Association (ABEn - Associação Brasileira de Enfermagem) Salvador, Bahia, Brazil, 2018

\begin{tabular}{|c|c|}
\hline Newspaper Clipping & Theme \\
\hline $\begin{array}{l}\text { Nurses all over Brazil will be mobilized on } 27 \text { and } 28 \text { of the present month, taking part in the direct elections for changing the Board of } \\
\text { Directors of the Brazilian Nursing Association, at national and local level, for the 4-year term 84/88. (35.1984) }\end{array}$ & \multirow{3}{*}{$\begin{array}{l}\text { ABEn } \\
\text { elections }\end{array}$} \\
\hline $\begin{array}{l}\text { Members from the opposition ticket "Participation", dissatisfied with what they consider fraud in the vote counting process } \\
\text { during elections for the Board of Directors in the Brazilian Nursing Association, filed for a preliminary injunction order in court, } \\
\text { in Brasilia, aiming to make the election null and void. (36.1984) }\end{array}$ & \\
\hline $\begin{array}{l}\text { Regarding accusations of fraud by members of the defeated ticket, the elected president commented on the candor of all procedures. } \\
\text { (A39-1984) }\end{array}$ & \\
\hline $\begin{array}{l}\text { Maria Ivete denounced the insensitivity of organizations that work with health care in private practice, because they do not take into } \\
\text { consideration the risk a patient runs as he is treated by a layman. The only reversion for this situation, for the new ABEn president, } \\
\text { would be to take down Law 2.604, which rules professional hiring. According to the bill that is under process for two years, } \\
\text { management positions in health services of institutions, differently from now, would be positions reserved exclusively for graduated } \\
\text { nurses. [.... Maria Ivete guaranteed that her leadership will drive efforts to approve the bill and, as soon as she comes into her } \\
\text { position, she will demand out of presidential candidate Tancredo Neves to commit with the nursing class so, if he is elected, he shall use } \\
\text { his influence beneficially for the nurse profession. (41.1984) }\end{array}$ & $\begin{array}{l}\text { Update of } \\
\text { Professional } \\
\text { Practice Law }\end{array}$ \\
\hline
\end{tabular}

Chart 2 - Militancy of nurses in the institutional framework of Federal and Regional Nursing Councils (COFEN and COREN-BA - Conselhos Federale Regional de Enfermagem), Salvador, Bahia, Brazil, 2018

\begin{tabular}{|c|c|}
\hline Newspaper Clipping & Theme \\
\hline $\begin{array}{l}\text { Nurses Jandira Santos Orrico, president of ABEn - Bahia section and Haidée Guanais Dourado, founder and first director of the } \\
\text { Nursing School of UFBa, are members of the Federal Nursing Council, recently established by Labor Minister Arnaldo Pietro. [...] This } \\
\text { council is an old revindication from nurses, and the nurse Iraildes Andrade, from Bahia, stands out in the fight for its creation. (9.1975) }\end{array}$ & $\begin{array}{l}\text { COFEN } \\
\text { establishment }\end{array}$ \\
\hline $\begin{array}{l}\text { Two tickets are already enrolled to run for the elections of the I Regional Nursing Council, legislative and disciplinary authority for } \\
\text { professional practice. [...] The institution, as soon as it is installed in Bahia, will not allow any nurse to practice the profession without being } \\
\text { registered in its ranks, whereas it will offer all the support for professional practice. (11.1975) }\end{array}$ & \multirow{2}{*}{$\begin{array}{l}\text { COREN-BA } \\
\text { elections }\end{array}$} \\
\hline $\begin{array}{l}\text { Nurses from Bahia elected the first director for the Regional Nursing Council - Bahia Section, in a most competitive run. All } \\
\text { nurses from Bahia attended the voting booths, a never-before-seen fact in a professional class election. (12.1975) }\end{array}$ & \\
\hline $\begin{array}{l}\text { COREN was created by Law } 5905 \text { from July } 12,1973 \text { and aims at regulating, regimenting and inspecting professional nursing } \\
\text { practice, said nurse Iraíldes Andrade. It is also an institution that will revendicate improvements for the nursing class, such as the } \\
\text { imposition of minimum wages and defined work shifts, which are so far inexistent. (14.1975) }\end{array}$ & \multirow{3}{*}{$\begin{array}{l}\text { COREN-BA } \\
\text { activities }\end{array}$} \\
\hline $\begin{array}{l}\text { On the other hand, Sônia Passos says that COREN will inspect nursing practice with more rigor and survey in hospitals and clinics is } \\
\text { already underway to determine whether nursing professionals are registered at the council. [...] Thus, indirectly, the kind of personnel } \\
\text { that is working in the nursing field is under scrutiny [...] (20.1980) }\end{array}$ & \\
\hline $\begin{array}{l}\text { [...] Arléo highlights, adding that, through the inspection of the work market, the institution also intends to draw limits to the practice } \\
\text { of nurses, who are almost always overburdened with other tasks in her workplaces [...] But there are still many professionals who are not } \\
\text { legally authorized by the council, thus, illegally practicing the profession, the president alerts [...]. (31.1982) }\end{array}$ & \\
\hline $\begin{array}{l}\text { The President of the Regional Nursing Council of Bahia, Iraídes Teixeira de Carvalho Andrade, confirmed the existence of a draft bill } \\
\text { aiming to reform the law that presently regulates the nursing profession, since it is already outdated. (15.1976) }\end{array}$ & \multirow{2}{*}{$\begin{array}{l}\text { Update of } \\
\text { Professional } \\
\text { Practice Law }\end{array}$} \\
\hline $\begin{array}{l}\text { Law 2.604/55, which rules the practice of Nursing in Brazil, and which is regulated by Decree } 50.387 / 61 \text {, is in need of reformulation. } \\
\text { The Federal Nursing Council, moreover, has two bills already under process at the Federal Congress, aiming to improve that } \\
\text { legislation, which, for Maria Ivete de Oliveira, is obsolete. (25.1980) }\end{array}$ & \\
\hline
\end{tabular}


Chart 3 - Militancy of nurses in the institutional framework of Nurses of Bahia State Union (SEEB - Sindicato dos Enfermeiros do Estado da Bahia), Salvador, Bahia, Brazil, 2018

\begin{tabular}{|l|c|}
\hline \multicolumn{1}{|c|}{ Newspaper Clipping } & Theme \\
\hline $\begin{array}{l}\text { Nursing Week starts today, and this year it will have a special celebration because nurses wish to found their professional Association, } \\
\text { a step towards the creation of Nurses' Union. (3.1973) }\end{array}$ & $\begin{array}{c}\text { Movement } \\
\text { to create the } \\
\text { Union }\end{array}$ \\
\hline $\begin{array}{l}\text { [...] she [Maria Olinda da Silva] and other companions are fighting for the creation of an entity that defends the professional interests } \\
\text { of the class. The Pro-Union Committee was formed for that. [...] Maria Olinda, however, assures that difficulties are being faced for } \\
\text { the professional normalization of nurses, and that the lack of awareness is the worst part. She shows, for example, that the Union was } \\
\text { in attempts to be created several times, but it never came to be. (17.1979) }\end{array}$ & $\begin{array}{l}\text { Unionizing } \\
\text { campaign }\end{array}$ \\
\hline \begin{tabular}{l} 
Theard of directors is in unionizing campaign, with a goal to be reached until June. (31.1982) \\
\hline
\end{tabular}
\end{tabular}

Regarding ABEn, in addition to commitment to seek the current Professional Practice Law's approval, which will be discussed later, the media highlighted Brazil's electoral dispute by board of directors' entity as a movement that sought to restructure the association. The'Participation Movement' began focusing on the opposition of the central board's work and some state sections, having as the maximum tension point the election of $1984^{(2)}$.

The movement was engendered by the interest of transforming ABEn's activities, which, according to the opposition group, has been adopting an authoritarian attitude, since it prevented member participation in decisive processes, and served government and multinational companies' political interests ${ }^{(18)}$. The movement precursors intended to break with this hegemony, leading to power a steering group that was, in fact, representative of the category yearnings. That was an attempt that carried the context of country redemocratization's ideology characterized by struggles in health and education.

What draws attention in this context is democratizing struggles incorporation on the nursing's part, following the same protest movements tendency that were drawn in the country's social and political overview. The opposition evidenced by this Movement was not intended only to oppose the ticket that had been in power, but to defend new political principles, as opposed to the conservative orientation that always characterized the entity ${ }^{(19)}$. Regardless of the ideologies and directions pursued by the association, it is understood, as literature points out ${ }^{(20)}$ that the movement made it possible for nurses to reflect and debate about entity organization and health transformation struggle, which would consolidate with the creation of the Brazilian Unified Health System (Sistema Único de Saúde) in 1988.

The aforementioned newspaper acted as a spokesperson to notify the divergent position of both groups, but did not display informative information on this movement meaning for nursing, being only the power dispute between two groups.

This movement protagonism in Bahia was in charge of nurses Stella Barros and Maria Ivete Ribeiro, which points to the political struggle within the nursing of Bahia. Stella Barros was a professor at UFBA's School of Nursing, and was running for vice president. Maria Ivete, besides having already worked as professor and director at the same school, was also ABEn-BA president and COFEN director.

Power and perpetuation struggle in decision-making spaces was clearly presented in another research ${ }^{(21)}$, which described how the political game permeated the choice of leaders in ABEn. According to the aforementioned study, parties' composition for the association's board of directors was made possible by interests and indications, so that they were already occupying power positions in both representative organizations and universities. Therefore, these leaders' choice did not happen by chance, and can be understood here from two different perspectives.

The first of these would be the interest for power perpetuation in a different representative sphere, since leaderships took turns among the School of Nursing professors. Nurses who moved in these spaces had more opportunities to engage in critical discussions on political and social issues, which would justify engagement in the association. Moreover, participating in the board conferred certain status and influence, since the entity, in that period, maintained articulations of interest with the government and with companies for financing ${ }^{(21)}$.

The other perspective is based on the absence of nurses interested in directing the class entity, since the fragility of political consciousness historically characterizes this category. Researchers ${ }^{(3)}$ point out that overall nurses do not have a broad understanding of political processes, making it difficult to reflect and criticize them to mobilize and reconstruct their actions.

This fact shows that the press use to release news related to the association was somewhat punctual, being a mere political strategy, since this entity's organizational aspects were only approached again by the newspaper in the late 1980s, when it was reported there was a new ticket-to-run formation for the 1989 elections. It can be observed, therefore, that ABEn was not characterized as a subject of interest for the periodical. Its representatives sought to use this tool to raise awareness of the category and expand the membership.

About COFEN, the press reported that nurses from Bahia participated in its implementation, and the effort undertaken with $A B E n$ to update the Professional Practice Law. With regard to COREN, section Bahia, the media announced the election and inauguration of the institution's first board of directors. That evidenced the institution's regulatory and supervisory nature.

ABEn's struggle for Board creation began in the 1940s, and it lasted for almost three decades, until Law 5,905 adoption in 1973, which created the COFEN/COREN System ${ }^{(2)}$. The Ministry of Labor took over the Council members in 1975. A group of nurses selected by ABEn was responsible for COREN and COFEN implementation $^{(22)}$. This group of counselors, which Jandira dos Santos Orrico was in, elected the first COFEN board, which proposed an important agenda of activities for the 12 months of work, including draft preparation to update the Professional Practice Law and CORENs establishment ${ }^{(22)}$. 
The news about the Council creation was publicized in a positive way, mainly by the massive participation of nurses in the election to the first COREN-BA board and as a result of affirmations that the body would contribute to profession status' regulation and elevation. According to Nair Fabio Silva, a nurse who was part of the COREN-BA's special Board, category reacted positively, considering that it was necessary to create a supervisory body to legitimize professional practice autonomy ${ }^{(23)}$.

Under a sociological analysis of professions, Professional Council creation allowed control and defense of the labor market ${ }^{(24)}$. Moreover, this creation was attended to by health care professionals, as nursing was increasing the number of workers, which made it necessary to ensure the quality of this practice through regulation and supervision.

At the same time, health services network expansion in Brazil in the second half of the twentieth century has increased the demand for professionals to make up new jobs. However, mediated by economic interests, numerous institutions opted for the hiring of lower-cost labor, replacing nurses with personnel with no university education. As a result, a large contingent of unskilled workers was incorporated, accounting for, at the time, more than $50 \%$ of the total workforce in the category ${ }^{(25)}$.

Nursing practice was regulated by Law 2,604/55 in this period, which enabled the six categories for nursing: nurse, nursing assistant, obstetrician, midwife, practical midwife, and practical nurse. However, the lack of supervision favored the performance of other unregulated categories, such as nursing assistants ${ }^{(26)}$. The Council creation began to regulate nursing professions as nursing technician, nursing assistant and obstetrician, who would have their work inspected and legally protected. The function of supervising nursing practice, hitherto conferred on the Brazilian National Medicine Supervision System (Sistema Nacional de Fiscalização da Medicina), became the responsibility of a proper nursing body, which allowed greater autonomy for the development of actions that allowed class representation.

Immediately after its implementation, the Council and the Association acted together and engaged in the adoption of a new Professional Practice Law, arguing that the old legal instrument did not guarantee the nurses' labor rights nor the quality of care provided.

Work fragmentation in nursing discharged and disqualified scientifically and economically nurses' work, since health care companies replaced these professionals by lower cost labor, admitting personnel without adequate qualification ${ }^{(25)}$. Commitment to Law 7,498/86 approval was motivated by the interest in guaranteeing the progress already made, and preserving the profession status, serving as a strategy to regulate the personnel authorized to act in nursing and to delimit the attributions of each worker in the area ${ }^{(27)}$.

In view of the above, Councils emergence brought contributions to nursing, although it is pertinent to point out that this also proved to be a strategy to meet the market needs of the government, since it was necessary to regulate the huge contingent of professionals without proper training that practiced nursing in the country.

After Council implementation in Bahia, the press was used by organization officers to notify to nursing staff and health services the obligation to register these professionals in the class council, under penalty of illegal profession practice in case it is not applied.
In addition to the interests presented, the body stated in a recent publication $^{(23)}$ that the effort to regularize professional records was also motivated by the economic crisis that reached COREN-BA in the late 1970s. The federal system's administrative and financial decentralization for the state resulted in an COREN finances imbalance. The solution found was to intensify the gathering of delinquent cases and increase gathering. Thus, actions focused again on obligation disclosure to register in the local authority ${ }^{(23)}$.

In addition to the publication of news about COFEN and CORENs creation, this newspaper's coverage about SEEB. In this case, as with Council, union creation took place through $A B E n$, in view of the need for an entity that intervened exclusively in labor matters.

Although the association positioned in defense of nurses' interests, including in relation to work, a union creation was essential for working in fields that were outside the competence of the association. Some actions, such as collective labor contracts conclusion of disputes, and striking movements organization are the exclusive competence of trade unions ${ }^{(28)}$.

In this perspective, trade unions are another form of professional representation and political organization, designed to defend the economic and social interests of a certain group of workers, having as a priority objective the struggle for better wages and working conditions ${ }^{(11)}$.

Opening the military regime and other social events that unfolded in the 1970s allowed reorganization and expansion of the Brazilian trade unionism. Several trade unions were set up, including SEEB in the early $1980 \mathrm{~s}^{(29)}$.

Mobilization for the creation of a nurses' union began in the 1970s, after the Professional Association founding in 1973, and later, the Pro-Union Committee implementation in 1979. Once the Associação Profissional de Enfermeiros do Estado da Bahia (APEB - freely translated as Professional Association of Nurses of Bahia State), this and ABEn-BA created a commission to accelerate the process of inauguration of Nurses' Union ${ }^{(30)}$.

The Sindicato de Profissionais em Enfermagem, Técnicos, Duchistas, Massagistas e Empregados de Hospitais e Casas de Saúde (freely translated as Nursing Professionals, Technicians, Duchesses, Masseurs and Employees of Hospitals and Health Homes Union), which represented all those workers in the area who did not have their own union, did not represent the real interests of nurses, who creation of an exclusive trade union, although it existed at the time ${ }^{(28)}$. However, fragile articulation and class consciousness permeated this overall category, demonstrating that certain advances were achieved by the exclusive commitment of small groups organized in representative entities. As pointed out in one of the reports, this was understood as one of the main factors that hindered the political and organizational development of the profession. However, it should be noted that the projected media image does not necessarily represent the lived reality, but rather the vision of a group and of people who formulate their opinion on a certain theme.

It should be noted that the low value attributed to the union is not a characteristic of the Bahian nurses, since other states experienced similar difficulty in the creation of their unions ${ }^{(29,31)}$. In this case, the low participation of nurses may be associated with repression in the professional field and the social stigmas that assimilate unionism to subversion ${ }^{(29)}$. 
Authors $^{(32)}$ point out that the lack of engagement in favor of the profession can originate in the academic formation of these nurses, based on rules and traditions of the Anglo-Saxon model, which did not favor political participation. For these authors, "nurses defined their union identity, learning in the militancy the art of military", through the coexistence with other workers and in the daily struggles ${ }^{(32)}$. Thus, when SEEB was finally created in 1981, its representatives circulated in the media some news that indicated the entity as a possible instrument of intervention in the problems associated with work practice and as instances of defense of professional rights.

Notifying the existence of an exclusive union of the category, the legal support offered by it and its possible contributions favors the reflection of nurses on their insertion in the labor market and the relations established by it, besides encouraging awareness of labor causes engagement.

Reports on precariousness of work and devaluation of nurses were sometimes found on the pages of $A$ Tarde, evidencing discontentment with labor issues. These reports, while fulfilling the role of notifying to society and to the category itself about problems that afflict nurses, are not able to solve them. A professional class demands can hardly be achieved unless there is joint and organized action by a consistent union.

The difficulty of nursing to perceive the inequalities that permeated the labor relations and to organize the category to fight them is related to the historical construction of the feminine profession, based on moralism and religious dogmas and lacking a political dimension ${ }^{(32)}$.

\section{Study limitations}

Short explanation about a particular fact or subject characteristic of journalistic reporting stands out as study limitation, making it difficult to understand the idea to be conveyed. In addition, absence of other studies to discuss the findings made other interpretations difficult, which, on the other hand, adds value to this research when presenting previously unpublished aspects.

\section{Contributions to Nursing}

The evidence presented allows understanding historical facts from the perspective of journalism, helping nurses to rethink their organizational practice and encourage actions aimed at political awareness, as well as reflecting on profession guiding aspects and factors favoring increased visibility and professional status. It is important to highlight the importance of journalistic sources valorization as a historical document to be preserved and treated as a possibility for a wide discussion of events in society, in this case, testifying nuances of nursing professional life and providing new studies.

\section{FINAL CONSIDERATIONS}

Nurses' professional militancy was present in the reorientation of $A B E N$ conceptions and in the involvement for creation of the Nurses' Council and Union. However, the visibility imparted by the media to the democratization movement of ABEn was superficial, lacking to clarify to the society important elements about the process that was in course. In this sense, the newspaper served only as a spokesperson for the groups to express their positions, evidencing whether it is a struggle for power and perpetuation of leaderships in the political space of the association.

COREN and COFEN creation was published by said newspaper, always with a positive character, as the possible alternative to solve the problem arising from professional practice without proper training. However, it did not portray the other interests intrinsic to the council and neither to the government. Since reports covered only members of the board's perspectives, it was concluded that this vehicle of communication served as an instrument for the body to notify registration obligation of professionals in the class council, so that inspection work, which would effectively guarantee benefits to the category, was not prioritized.

With regard to union creation, the data point to the fragile understanding of professionals about the need for mobilization by the political struggle as a difficult factor. Although the country's historical context favored demand struggles, nurses' training model, labor market conditions, and stigmas that followed trade unionism were understood as distancing militancy determinants.

Organization of these spaces of action occurred, to a large extent, through efforts of professionals who were already working in association and university scope. However, mobilization did not occur uniformly in the category, being restricted to small groups of professionals engaged, demonstrating nurses' fragile political awareness.

Category reduced involvement in political issues made it unfeasible for discussions from other points of view and diverse practice setting, so that ideas disseminated by press reverberated groups convictions and interests, since the collective assumed an exemption decision-making. Nevertheless, ABEn was active, counting on nurses from Bahia participation as Brazilian nursing representatives.

\section{FUNDING}

This study was funded by the School of Nursing of Universidade Federal da Bahia.

\section{REFERENCES}

1. Baltazar B. Encontros e desencontros da militância na vida cotidiana. Psic: Teor Pesq. 2004;20(2):183-90. doi: 10.1590/S0102-37722004000200011

2. Geovanini T. História da Enfermagem: versões e interpretações. 3. ed, Rio de Janeiro: Revinter; 2010.

3. Lessa ABSL, Araújo CNV. A enfermagem brasileira: reflexão sobre sua atuação política. Rev Min Enf. 2013;17(2):474-80. doi: $10.5935 / 1415-2762.20130036$

4. Pires CDO, Melo CMM. Gênese do movimento estudantil na Escola de Enfermagem da Universidade Federal da Bahia (1947-1959). Esc Anna Nery. 2008;12(3):437-43. doi: 10.1590/\$1414-81452008000300007 
Militancy of nurses in the institutionality field: printed media versions

5. Almeida DB, Queirós PJP, Silva GTR, Laitano ADC, Almeida SS. Sexist stereotypes in portuguese nursing: a historical study in the period 1935 to 1974. Esc Anna Nery. 2016;20(2):228-35. doi: 10.5935/1414-8145.20160030 Portuguese

6. Almeida DB, Silva GTR, Queirós PJP, Freitas GF, Laitano ADC, Almeida SS, et al. Portuguese nursing: history of the life and activism of Maria Augusta Sousa. Rev Esc Enferm USP. 2016;50(3):495-501. doi: 10.1590/S0080-623420160000400017 Portuguese

7. Sousa RC. Associativismo feminino e participação política: um estudo sobre as bases sociais de apoio à Ditadura Militar em Curitiba (19641985). Estud Hist (Rio J.). 2018;31(65):389-412. doi: 10.1590/s2178-14942018000300005

8. Cardoso RJM, Graveto JMGDN, Queiroz AMCA. The exposure of the nursing profession in online and print media. Rev Latino-Am Enfermagem. 2014;22(1):144-9. doi: 10.1590/0104-1169.3144.2394 Portuguese

9. Conselho Federal de Enfermagem. Enfermagem em números [Internet]. Salvador; 2018[cited 2017 Oct 11]. Available from: http://www. cofen.gov.br/enfermagem-em-numeros

10. Oliveira NL. História das diretoras da Escola de Enfermagem da Universidade Federal da Bahia (1946-1956). [Dissertação] [Internet]. Salvador (BA): Universidade Federal da Bahia; 2016[cited 2017 Oct 11]. Available from: https://pgenf.ufba.br/sites/pgenf.ufba.br/files/7._dissertacao_nubia_lino.pdf

11. Almeida DB, Silva GTR, Queiros PJP, Freitas GF, Almeida IFB. Lúcia Esther Duque Moliterno: knowing the life story of a militant nurse. Rev Enferm UERJ. 2017;25:e13345:1-5. doi: 10.12957/reuerj.2017.13345 Portuguese

12. Almeida DB, Silva GTR, Queiros PJP, Freitas GF, Almeida IFB. Life story of Josicélia Dumêt Fernandes, teacher and nurse. Rev Enferm UERJ. 2017;25(1):1-5. doi: 10.12957/reuerj.2017.17105 Portuguese.

13. Almeida DB, Silva GTR, Freitas GF, Padilha MI, Almeida IFB. Discursive archaeology: constituting knowledge of militant nurses in trade associations. Rev Bras Enferm. 2018;71(3):1194-201. doi: 10.1590/0034-7167-2017-0277 Portuguese

14. Miranda NM. Jornalistas em cena, artistas em pauta: Análise da cobertura jornalística dos espetáculos teatrais baianos realizados pelos jornais A Tarde e Correio da Bahia na década de 90 [Dissertação] [Internet]. Salvador (BA): Universidade Federal da Bahia; 2001 [cited 2017 Oct 11]. Available from: http://www.repositorio.ufba.br:8080/ri/bitstream/ri/9669/1/Nadja_dissertacaoseg.pdf

15. Ghilardi-Lucena MI. Representações do gênero masculino na mídia impressa brasileira. In: 4o SOPCOM: "Repensar os Media: Novos Contextos da Comunicação e da Informação" [Internet]. 2005 [cited 2017 Oct 11];1018-25. Available from: http://www.bocc.ubi.pt/pag/ ghilardi-maria-representacoes-genero-masculino-midia-imprensa-brasileira.pdf

16. Barros JD. O projeto de pesquisa em história: da escolha do tema ao quadro teórico. Petrópolis: Vozes; 2017.

17. Franco MLPB. Análise de conteúdo. 4 ed. Brasília: Liber Livro Ltda; 2012.

18. Albuquerque GL, Pires DEP. O Movimento Participação (MP): uma contribuição à história da enfermagem brasileira. Rev Bras Enferm. 2001;54(2):174-84. doi: 10.1590/S0034-71672001000200003 Portuguese

19. Germano RM. Percurso revisitado: o ensino de enfermagem no Brasil. Pro Posições [Internet]. 2003 [cited 2018 Jan 16];14(1):13-28. Available from: https://periodicos.sbu.unicamp.br/ojs/index.php/proposic/article/view/8643901/11369

20. Albuquerque GL. O Movimento Participação na Associação Brasileira de Enfermagem - Seção Santa Catarina, na visão de suas principais lideranças [Tese]. Florianópolis (SC): Departamento de Enfermagem, UFSC; 2001.

21. Almeida DB. Constituição de Enfermeiras Militânites: um estudo histórico e foucaultiano [Tese]. Salvador (SC): Universidade Federal da Bahia, 2017.

22. Garcia CLLM, Moreira A. A Associação Brasileira de Enfermagem e a criação do conselho profissional no Brasil. Rev Pesqui: Cuid Fundam. 2009;1(1):97-110. doi: 10.9789/2175-5361.2009.v1i1.\%25p

23. Conselho Regional de Enfermagem da Bahia. Coren-BA: 40 anos de história (1975-2015). Salvador: Coren-BA; 2017. 201 p.

24. Bellaguarda MLR. Nexus e circunstâncias da história do Conselho Regional de Enfermagem em Santa Catarina (1975-1986) [Tese]. Florianópolis (SC): Universidade Federal de Santa Catarina; 2013.

25. Santos I, Souza AMA, Galvão EA. Subsídios para formulação de uma política de profissionalização para o pessoal de enfermagem sem qualificação específica. Rev Bras Enferm. 1988;41(1):75-80. doi: 10.1590/S0034-71671988000100013

26. Capella BB, Faria EM, Gelbcke FL, Spricigo JS. Profissionalização da enfermagem: uma necessidade social. Rev Bras Enferm. 1988;41(2):161-8. doi: 10.1590/S0034-71671988000200012

27. Gottems LBD, Alves ED, Sena RR. Brazilian nursing and professionalization at technical level: a retrospective analysis. Rev Latino-Am Enferm. 2007 [cited 2018 mar 8];15(5):1-9. doi: 10.1590/S0104-11692007000500023 Portuguese

28. Oguisso T. Trajetória histórica e legal da enfermagem. 2 ed. Sao Paulo: Manole; 2007.

29. Gomes MLB, Santos TCF, Da Luz M, Gomes B, Cristina T, Santos F. Construindo a identidade sindical das enfermeiras no rio de janeiro (19781984). Texto Context Enferm. 2005;14(4):488-97. doi: 10.1590/S0104-0707200500040000

30. Alcântara IP, Luckesi MAV, Paiva MS. Contando uma bela história: a trajetória da ABEn - Bahia. Rev Bras Enferm. 2001;53(4):271-7. doi: $10.1590 /$ S0034-71672001000200014

31. Carvalho VLS, Guimarães CM. Enfermagem e Sindicalismo em Goiás: análise do período 1982-2004. Rev Bras Enferm. 2007;60(2):155-60. doi: $10.1590 / 50034-71672007000200006$

32. Santos RM, Trezza MCSF, Barros WO, Leite JL. História e perspectivas da organização dos enfermeiros nos movimentos sindicais. Rev Bras Enferm. 2006;59(1):89-94. doi: 10.1590/S0034-71672006000100017 